\title{
Correction to: Reframing a debate in chiropractic
}

Henry Pollard ${ }^{*}$ (D)

\section{Correction to: Pollard Chiropr Man Therap (2021) 29:44 https://doi.org/10.1186/s12998-021-00401-5}

Following the publication of the original article [1], we were notified that two sentences contained information that did not correctly reflect recent events, and therefore have been removed. Reference 73 has been also removed and subsequent references have been renumbered.

The original article has been corrected.
Reference

1. Pollard et al. (2021) Reframing a debate in chiropractic (2021) 21:44 https://doi.org/10.1186/s12998-021-00401-5

\section{Publisher's Note}

Springer Nature remains neutral with regard to jurisdictional claims in published maps and institutional affiliations.

Published online: 22 November 2021

The original article can be found online at https://doi.org/10.1186/s12998021-00401-5.

*Correspondence: hpollard@optushome.com.au

Department of Chiropractic, School of Medical and Applied Sciences,

CQUniversity, Brisbane, Australia original author(s) and the source, provide a link to the Creative Commons licence, and indicate if changes were made. The images or other third party material in this article are included in the article's Creative Commons licence, unless indicated otherwise in a credit line to the material. If material is not included in the article's Creative Commons licence and your intended use is not permitted by statutory regulation or exceeds the permitted use, you will need to obtain permission directly from the copyright holder. To view a copy of this licence, visit http://creativecommons.org/licenses/by/4.0/. The Creative Commons Public Domain Dedication waiver (http://creativecommons.org/publicdomain/zero/1.0/) applies to the data made available in this article, unless otherwise stated in a credit line to the data. 